\title{
Pengaruh Kecerdasan dan Love of Money terhadap Persepsi Etis Mahasiswa
}

Akuntansi

\author{
Ida Ayu Ratih Manuari ${ }^{1}$ \\ Fakultas Ekonomi dan Bisnis \\ Universitas Mahasaraswati Denpasar, \\ Indonesia
}

\author{
Ni Luh Nyoman Sherina Devi² \\ Fakultas Ekonomi dan Bisnis \\ Universitas Mahasaraswati Denpasar, \\ Indonesia
}

\begin{abstract}
Surel : ratih.manuari@gmail.com
\section{ABSTRAK}

Penelitian bertujuan untuk mengetahui pengaruh kecerdasan intelektual, kecerdasan emosional, kecerdasan spiritual, dan love of money terhadap persepsi etis mahasiswa akuntansi. Tujuan dari pendidikan akuntansi adalah untuk mengenalkan mahasiswa kepada nilai-nilai dan standar-standar etik dalam profesi akuntan. Pentingnya etika dalam suatu profesi membuat profesi akuntan memfokuskan perhatiannya pada persepsi etis para mahasiswa akuntansi sebagai titik awal dalam meningkatkan persepsi terhadap profesi akuntansi, sehingga masih sangat dibutuhkan penelitian mengenai etika pada mahasiswa akuntansi. Sampel dipilih menggunakan metode nonprobability sampling dengan total sampel sebanyak 75 responden dan digunakan analisis regresi linear berganda sebagai alat pengujian. Hasil penelitian menunjukkan bahwa kecerdasan spiritual dan love of money berpengaruh positif pada persepsi etis mahasiswa akuntansi. Kecerdasan intelektual dan kecerdasan emosional ditemukan tidak berpengaruh pada persepsi etis mahasiswa akuntansi.
\end{abstract}

Kata Kunci: Kecerdasan; Love of Money; Persepsi Etis.

\section{The Effect of Intelligence and Love of Money on the Ethical Perceptions of Accounting Students}

\begin{abstract}
This study aims to determine the effect of intellectual intelligence, emotional intelligence, spiritual intelligence, and love of money on the ethical perceptions of accounting students. The purpose of accounting education is to introduce students to values and ethical standards in the accounting profession. The importance of ethics in a profession makes the accounting profession focus its attention on the ethical perceptions of accounting students, as a starting point in increasing perceptions of the accounting profession. therefore, research on ethics in accounting students is needed. The sample was selected using nonprobability sampling method with a total sample of 75 respondents and used multiple linear regression analysis as a testing tool. The results showed that spiritual intelligence and love of money had a positive effect on the ethical perceptions of accounting students. Intellectual intelligence and emotional intelligence were found to have no effect on ethical perceptions of accounting students.
\end{abstract}

Keywords: Intelligence; Love of Money; Ethical Perception.

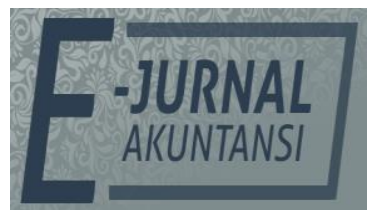

e-ISSN 2302-8556

Vol. 30 No. 11

Denpasar, Nopember 2020 Hal. 2969-2982

DOI:

10.24843/EJA.2020.v30.i11.p19

PENGUTIPAN:

Manuari, I.A.R. \& Devi,

N.L.N.S. (2020). Pengaruh

Kecerdasan dan Love of Money terhadap Persepsi Etis Mahasiswa Akuntansi. EJurnal Akuntansi, 30(11), 2969-2982

RIWAYAT ARTIKEL:

Artikel Masuk:

31 Oktober 2020

Artikel Diterima: 27 November 2020

Artikel dapat diakses : https://ojs.unud.ac.id/index.php/Akuntansi/index 


\section{PENDAHULUAN}

Isu-isu etika dalam dunia bisnis dan profesi membuat perhatian masyarakat menjadi meningkat, hal tersebut dikarenakan skandal-skandal perusahaan besar terjadi dan ini tentu tidak terlepas dari rendahnya kualitas opini audit yang mengakibatkan salahnya pengambilan keputusan stakeholder perusahaan. Salah satu contoh fenomena pelanggaran kode etik yang dilakukan oleh profesi akuntan adalah sengaja melakukan window dressing terhadap laporan keuangan klien agar mendapat dana bank untuk ekspansi, contoh fenomena pelanggaran kode etik lainnya adalah seorang auditor suatu perusahaan merangkap sekaligus menjadi konsultan manajemen perusahaan tersebut atas permintaan dari klien. Skandal yang pernah terjadi di dunia maupun Indonesia adalah sebagai berikut: kasus HIH Insurance dan One Tel di Australia, kasus Enron, Health South, AIG, Subprime Loans, WorldCom dan Global Crossing di Amerika; Parmalat di Eropa; Satyam di India, dan untuk di Indonesia adalah kasus PT. Kimia Farma dan pajak PT. Bumi Resources.

Skandal akuntansi bukanlah hal baru di Indonesia, salah satu kasus yang ramai diberitakan adalah keterlibatan 10 Kantor Akuntan Publik di Indonesia dalam praktik kecurangan keuangan. Kantor Akuntan Publik tersebut ditunjuk untuk mengaudit 37 bank sebelum terjadinya krisis keuangan pada tahun 1997. Hasil audit mengungkapkan bahwa laporan keuangan bank-bank tersebut sehat. Saat krisis menerpa Indonesia, bank-bank tersebut kolaps karena kinerja keuangannya sangat buruk. Ternyata baru terungkap dalam investigasi yang dilakukan pemerintah bahwa Kantor Akuntan Publik tersebut terlibat dalam praktik kecurangan akuntansi (Suryana, 2002).

Tujuan dari pendidikan akuntansi adalah untuk mengenalkan mahasiswa kepada nilai-nilai dan standar-standar etik dalam profesi akuntan (Clikemen \& Henning, 2000). Kepedulian terhadap etika harus diawali dari kurikulum akuntansi, jauh sebelum mahasiswa akuntansi masuk ke dunia profesi akuntansi (Mastracchio, 2005). Elias dan Faraq berpendapat bahwa mahasiswa akuntansi sekarang adalah para profesional di masa depan dan dengan pendidikan etika yang baik diharapkan dapat menguntungkan profesinya dalam jangka panjang. Karena begitu pentingnya etika dalam suatu profesi, membuat profesi akuntansi memfokuskan perhatiannya pada persepsi etis para mahasiswa akuntansi sebagai titik awal dalam meningkatkan persepsi terhadap profesi akuntansi, sehingga masih sangat dibutuhkan penelitian mengenai sosialisasi tentang etika pada mahasiswa akuntansi (Elias \& Faraq, 2010).

Tujuan pendidikan tidak hanya mengenai kecerdasan intelektual saja. Pendidikan juga harus dapat mengembangkan peserta didik dari segi emosi, sikap, dan kemampuan spiritual. Dengan kata lain, pendidikan harus dapat mengembangkan kecerdasan emosional dan kecerdasan spiritual agar peserta didik dapat menjadi insan yang tidak hanya berilmu namun juga memiliki sikap etis (Fadli \& Djamhuri, 2014).

Kecerdasan intelektual, kecerdasan emosional, dan kecerdasan spiritual muncul karena adanya kesadaran untuk bertindak dari mahasiswa akuntansi. Theory of Planned Behavior (TPB) menyatakan bahwa manusia cenderung bertindak sesuai dengan intensi dan persepsi pengendalian melalui perilaku tertentu, dimana intensi mempengaruhi tingkah laku, norma subjektif serta pengendalian 
perilaku (Ajzen, 1988). Seperti hasil penelitian yang diungkapkan oleh Wardana \& Mimba (2016) menemukan bahwa kecerdasan intelektual, kecerdasan emosional, dan kecerdasan spiritual mahasiswa akuntansi memiliki pengaruh terhadap persepsi etisnya. Namun berbeda dengan hasil dari Fadli \& Djamhuri (2014) yang menemukan hasil berbeda yaitu kecerdasan intelektual tidak berpengaruh terhadap persepsi etis mahasiswa akuntansi.

Kecerdasan emosional juga merupakan faktor yang diduga mempengaruhi persepsi etis individu. Svyantek (2003) menyatakan kecerdasan emosional yang dimiliki oleh mahasiswa mampu mengetahui perasaan diri sendiri dan perasaan orang lain, serta menggunakan perasaan tersebut untuk menuntun pikiran dan perilaku seseorang agar tidak mengecewakan orang lain. Hasil berbeda ditemukan pada penelitian Tikollah, et al., (2006) yang menyatakan bahwa kecerdasan emosional tidak berpengaruh terhadap persepsi etis mahasiswa akuntansi

Kecerdasan spiritual juga diduga mempengaruhi persepsi etis seseorang, individu yang yang cerdas secara spiritual yaitu individu yang mampu menghadapi dan memecahkan persoalan hidupnya, mampu memberi makna dan nilai dalam hidupnya (Zohar \& Marshall, 2007). Mampu memecahkan masalah sesuai dengan kaidah yang ada dimasyarakat dan berpedoman sesuai dengan keyakinan (agama) yang dianutnya. Penelitian tentang kecerdasan emosional yang berpengaruh pada sikap etis mahasiswa akuntansi pernah dilakukan oleh Agustini \& Herawati (2013) yang menemukan hasil yang berpengaruh positif. Namun berbeda dengan hasil yang didapat oleh Fadli \& Djamhuri (2014) yang menemukan hasil kecerdasan spiritual tidak berpengaruh terhadap persepsi etis mahasiswa akuntansi

Kecerdasan intelektual, kecerdasan emosional dan kecerdasan spiritual memiliki pengaruh pada persepsi etis individu dalam hal ini mahasiswa akuntansi. Hal ini sejalan dengan apa yang ditegaskan oleh Tikollah et al., (2006) bahwa etika bukanlah sekedar masalah kecerdasan intelektual, tetapi lebih dari itu adalah masalah yang menyangkut dimensi emosional dan spiritual seorang mahasiswa. Penelitian Aprilianto \& Achmad (2017) mengungkap bahwa kecerdasan intelektual dan kecerdasan emosional mahasiswa akuntansi berpengaruh positif signifikan terhadap persepsi etis mahasiswa akuntansi. Persepsi etis dalam konteks mahasiswa akuntansi adalah suatu pola pikir (intensi) yang positif yang nantinya akan diwujudkan dalam bentuk sikap positif (etis).

Selain faktor kecerdasan, persepsi etis diduga dipengaruhi oleh faktor love of money, yaitu bagaimana sifat seseorang terhadap uang. Uang adalah aspek penting dalam kehidupan sehari-hari. Walaupun uang tersebut digunakan universal, namun arti dan pentingnya uang tidak begitu saja dapat diterima secara universal (Elias \& Faraq, 2010). Karena pentingnya uang dan interpretasi yang berbeda, Tang, (1992) memperkenalkan konsep "love of money" untuk literatur psikologis yang merupakan ukuran perasaaan subjektif seseorang tentang uang. Tang \& Chiu (2003) mengemukakan love of money sangat terkait dengan konsep ketamakan, konsep love of money merupakan karakter seseorang yang memuja atau mendewakan uang/materi lebih dari apapun tentu bagi seseorang yang memuja uang/materi dia akan melakukan berbagai cara untuk mendapatkan uang/materi. Chen \& Tang (2006) menemukan bahwa karyawan di Hong Kong 
dengan love of money yang tinggi bekerja dengan kurang memuaskan dibandingkan rekan-rekan mereka dan hal tersebut dapat menyebabkan perilaku yang tidak etis. Penelitian lainnya yaitu Elias \& Faraq (2010), Pradanti \& Prastiwi (2014), serta Manuari (2016) menemukan bahwa tingkat love of money mahasiswa akuntansi berpengaruh negatif terhadap persepsi etis mahasiswa tersebut, namun Widyaningrum \& Kamayanti (2013) mendapatkan hasil yang berbeda yaitu tingkat love of money mahasiswa akuntansi berpengaruh positif terhadap persepsi etis mahasiswa akuntansi.

Berdasarkan fenomena dan hasil penelitian terdahulu yang masih terdapat hasil penelitian yang berbeda, maka peneliti tertarik untuk mengangkat penelitian mengenai Pengaruh Kecerdasan Intelektual, Kecerdasan Emosional, Kecerdasan Spiritual, dan Love of Money terhadap Persepsi Etis Mahasiswa Akuntansi. Penelitian ini diharapkan akan sangat berguna untuk Universitas Mahasaraswati Denpasar terutama Program Studi Akuntansi dalam membentuk karakter lulusan akuntansi yang menjunjung tinggi kode etik dan profesionalismenya.

Teori utama yang digunakan dalam penelitian ini adalah Theory of Planned Behavioural, yang menjelaskan bahwa perilaku yang dimiliki seseorang merupakan suatu tindakan yang berakar dari intensi (niat). Niat tersebut dapat berupa pikiran yang dipengaruhi oleh persepsi seseorang. Persepsi yang dimiliki oleh seseorang tersebut dapat mempengaruhi tindakan atau perilaku yang akan dilakukan seseorang sehingga, Ketika seseorang melakukan tindakan atau perilaku yang baik maka dipercaya seseorang tersebut memiliki pikiran dalam hal ini adalah persepsi yang baik juga. Begitu pula sebaliknya apabila seseorang melakukan sesuatu yang tidak baik maka hal tersebut dipengaruhi oleh persepsi yang tidak baik juga. Pikiran yang dimiliki oleh seseorang dipengaruhi oleh niat (intensi) yang dimana hal ini mempengaruhi persepsi seseorang dan berujung pada tindakan yang dilakukan oleh individu tersebut.

Terdapat beberapa teori pendukung yang digunakan dalam penelitian ini, yaitu kecerdasan intelektual, kecerdasan emosional, kecerdasan spiritual dan the love of money. Sementara kajian empiris dalam penelitian ini berpedoman pada beberapa penelitian terdahulu, yaitu : penelitian Tang \& Luna-Arocas (2005), Lopez, et al. (2005), Chen \& Tang (2006), Elias \& Faraq (2010), Nkundabanyanga, et al. (2011), Widyaningrum \& Kamayanti (2013), Pradanti \& Prastiwi (2014), serta Wardana \& Mimba (2016). 


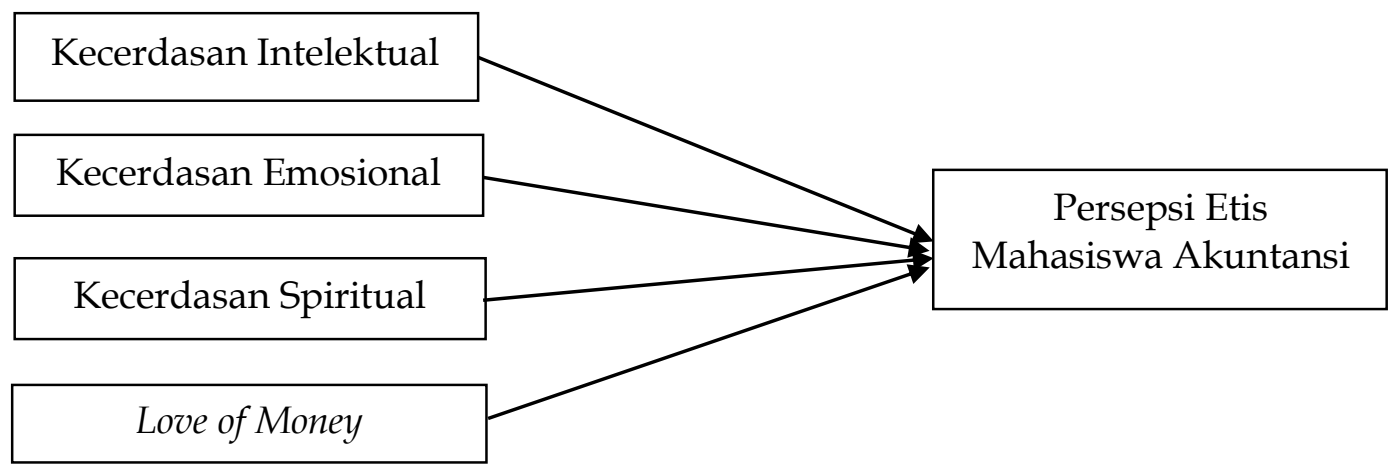

Sumber: Data Penelitian, 2020

\section{Gambar 1. Model Peneltian}

Tikollah, et al., (2006) menyatakan bahwa pandangan kelompok yang menekankan kecerdasan intelektual sebagai kemampuan adaptasi, serta orang yang inteligen (cerdas) akan memiliki kemampuan untuk mengorganisasi polapola tingkah lakunya sehingga dapat bertindak lebih efektif dan lebih tepat. Ini berarti bahwa makin tinggi inteligensi seseorang maka akan semakin terdorong untuk bersikap dan berperilaku etis.

Menurut Robbins dan Judge (2008: 52), kecerdasan intelektual adalah kemampuan yang dibutuhkan untuk melakukan berbagai aktivitas mental. Orang yang memiliki kecerdasan intelektual yang tinggi akan menggunakan logika untuk berpikir, sehingga tentunya akan lebih memahami apa yang dilakukan oleh seseorang dan apa akibat dari perbuatan itu. Menurut Purwanto (2003:52) Kecerdasan Intelektual adalah kesanggupan untuk menyesuaikan diri kepada kebutuhan baru, dengan menggunakan alat-alat berpikir yang sesuai dengan tujuan.

Penelitian sebelumnya mengenai pengaruh kecerdasan intelektual pada sikap etis mahasiswa akuntansi telah dilakukan oleh Tikollah et al., (2006), Jamaluddin (2011), Agustini \& Herawati (2013), serta Said \& Rahmawati (2018). Keempat penelitian tersebut memperoleh hasil bahwa kecerdasan intelektual berpengaruh positif pada persepsi etis mahasiswa akuntansi. Namun berbeda dengan hasil dari Fadli \& Djamhuri (2014) yang menemukan hasil berbeda yaitu kecerdasan intelektual tidak berpengaruh terhadap persepsi etis mahasiswa akuntansi. Dengan demikian, kecerdasan intelektual berpengaruh pada persepsi etis mahasiswa akuntansi dalam berperilaku dan berpikir secara rasional terhadap tingkah laku mereka. Karena masih terdapat inkonsistensi hasil peneitian maka, dapat dirumuskan hipotesis sebagai berikut.

$\mathrm{H}_{1}$ : Kecerdasan Intelektual berpengaruh positif pada persepsi etis mahasiswa akuntansi.

Menurut Melandy \& Aziza (2006) kecerdasan emosional memiliki peran lebih dari $80 \%$ dalam mencapai kesuksesan hidup, baik dalam kehidupan pribadi maupun kehidupan profesional. Menjadi seorang lulusan akuntansi yang berkualitas, diperlukan waktu yang panjang dan usaha yang keras serta dukungan dari pihak lain sehingga dapat mempengaruhi pengalaman hidup lulusan tersebut. 
Ciri-ciri lain dari kecerdasan emosional adalah memahami diri sendiri, mengenali emosi diri, dan mampu mengelola emosi diri Goleman (2009). Individu yang memiliki kecerdasan emosional dapat memahami peran dirinya dalam masyarakat yang berujung pada pemahaman bahwa individu tersebut harus mengikuti norma dan nilai yang ada di sekelilingnya. Dengan kemampuan mengenali dan mengelola emosi diri, maka individu dapat bertindak secara etis sesuai dengan norma dan nilai yang berlaku serta dengan tujuan menjaga hubungan dengan masyarakat.

Penelitian sebelumnya mengenai pengaruh kecerdasan emosional pada persepsi etis mahasiswa akuntansi telah dilakukan oleh Ika (2011), Jamaluddin (2011), Lucyanda (2013), Agustini \& Herawati (2013), Fadli \& Djamhuri (2014), dan Mangiskar (2019). Keenam penelitian tersebut memperoleh hasil bahwa kecerdasan emosional berpengaruh positif pada persepsi etis mahasiswa akuntansi. Hasil berbeda ditemukan pada penelitian Tikollah et al., (2006) yang menyatakan bahwa kecerdasan emosional tidak berpengaruh terhadap persepsi etis mahasiswa akuntansi. Dengan demikian, kecerdasan emosional berpengaruh pada persepsi etis mahasiswa akuntansi dalam mengontrol emosi mereka sesuai dengan kondisi dan situasi, sehingga dapat memberikan dampak yang positif serta berfungsi sebagai pendorong agar mahasiswa dapat memahami perasaan orang lain. Karena masih terdapat inkonsistensi hasil peneitian maka, dapat dirumuskan hipotesis sebagai berikut.

$\mathrm{H}_{2}$ : Kecerdasan emosional berpengaruh positif pada persepsi etis mahasiswa akuntansi.

Zohar \& Marshall (2007) menyatakan bahwa kecerdasan spiritual adalah "kecerdasan untuk menghadapi persoalan makna atau value, yaitu kecerdasan untuk menempatkan perilaku dan hidup manusia dalam konteks makna yang lebih luas dan kaya serta kecerdasan untuk menilai bahwa tindakan atau jalan hidup seseorang lebih bermakna dibandingkan orang lain". Maryani \& Ludigdo (2001) melakukan penelitian mengenai faktor-faktor yang memengaruhi sikap dan perilaku etis akuntan. Penelitian tersebut menunjukkan bahwa faktor religiusitas (kecerdasan spiritual) memengaruhi sikap etis akuntan. Sejalan dengan penelitian yang dilakukan oleh Ramly, et al. (2008) yang menyimpulkan religiusitas (kecerdasan spiritual) berpengaruh positif terhadap perilaku etis mahasiswa universitas di Malaysia.

Pada penelitian sebelumnya mengenai pengaruh kecerdasan spiritual pada sikap etis mahasiswa akuntansi telah dilakukan oleh Trihandini (2005), Ika (2011), Jamaluddin (2011), Agustini \& Herawati (2013), dan Rochmah (2013). Kelima penelitian tersebut memperoleh hasil bahwa kecerdasan spiritual berpengaruh positif pada sikap etis mahasiswa akuntansi. Sikap dan perilaku etis seseorag merupakan hasil akhir dari suatu persepsi sehingga dengan demikian, dapat kami Tarik suatu hipotesis bahwa kecerdasan spiritual berpengaruh pada persepsi etis mahasiswa akuntansi, dimana persepsi ini merupakan dasar individu dalam membentuk jati dirinya untuk bersikap dan berperilaku. Dasar ini pula yang dijadikan pedoman dalam mencari arti kehidupan dan bertindak berdasarkan nilai dan norma yang telah berlaku. Namun berbeda dengan hasil yang didapat oleh Fadli \& Djamhuri (2014) yang menemukan hasil kecerdasan spiritual tidak berpengaruh terhadap persepsi etis mahasiswa akuntansi. Karena 
masih terdapat inkonsistensi hasil peneitian maka, dapat dirumuskan hipotesis sebagai berikut.

$\mathrm{H}_{3}$ : Kecerdasan spiritual berpengaruh positif pada persepsi etis mahasiswa akuntansi.

Berdasarkan tiga hipotesis yang telah dirumuskan yang dimana bahwa kecerdasan tersebut memiliki pengaruh yang positif terhadap persepsi etis yang dimiliki mahasiswa akuntansi. Mahasiswa akuntansi yang merupakan seorang professional di masa depan adalah orang-orang yang nantinya kan mengelola uang dalam pekerjaannya misalkan menjadi seorang akuntan, manajer keuangan dan profesi lain yang mengatur keuangan suatu entitas. Ketika seseorang yang dekat dengan uang dipercaya tentunya memiliki kadar love of money terhadap dirinya.

Tang \& Chiu (2003) mendefinisikan love of money adalah karakter seseorang yang mendewakan uang dan love of money terkait erat dengan konsep "ketamakan" sehingga love of money dan sikap etis memiliki korelasi yang negatif. Semakin tinggi tingkat love of money yang dimiliki seseorang, maka akan semakin rendah sikap etis yang dimilikinya, begitu pula sebaliknya. Hal ini disebabkan karena apabila seseorang memiliki kecintaan uang yang tinggi, maka ia akan berusaha untuk melakukan segala cara agar kebutuhannya terpenuhi walaupun tidak sesuai dengan etika profesinya. Hubungan antara perilaku cinta uang dan sikap etis telah diteliti lebih lanjut di beberapa negara. Elias \& Faraq (2010) menguji hubungan love of money apabila dikaitkan dengan sikap etis menghasilkan hubungan yang negatif. Penelitian ini berbeda debgan hasil yang diperoleh oleh Widyaningrum \& Kamayanti (2013) mendapatkan hasil yang berbeda yaitu tingkat love of money mahasiswa akuntansi berpengaruh positif terhadap persepsi etis mahasiswa akuntansi. Karena masih terdapat inkonsistensi hasil peneitian maka, dapat dirumuskan hipotesis sebagai berikut.

$\mathrm{H}_{4}$ : Love of money berpengaruh negatif pada persepsi etis mahasiswa akuntansi.

\section{METODE PENELITIAN}

Penelitian ini bertujuan untuk mengetahui dan mengalisis pengaruh kecerdasan intelektual, kecerdasan emosional, kecerdasan spiritual, dan gender pada sikap etis mahasiswa akuntansi. Untuk menganalisis pengaruh tersebut data yang digunakan dalam penelitian ini adalah hasil pengisian kuesioner oleh mahasiswa akuntansi Program Studi Sarjana Akuntansi pada Universitas Mahasaraswati Denpasar. Dengan demikian, penelitian ini berlokasi pada mahasiswa Program Studi Sarjana Akuntansi pada Universitas Mahasaraswati Denpasar. Adapun waktu penelitian dilakukan pada tahun 2020.

Penelitian ini menggunakan pendekatan kuantitatif yang bersifat asosiatif. Penelitian ini menggunakan data primer yang diperoleh menggunakan metode survei melalui teknik kuesioner dengan cara mengedarkan daftar pernyataan yang akan diisi oleh responden. Data sekunder yang digunakan dalam penelitian ini adalah jumlah mahasiswa Program Studi Akuntansi Universitas Mahasaraswati semester V yang diperoleh melalui Sekretariat Fakultas Ekonomi dan Bisnis Universitas Mahasaraswati.

Data kuantitatif dalam penelitian meliputi data skor jawaban kuesioner yang terkumpul dan jumlah mahasiswa Program Studi Akuntansi Universitas 
Mahasaraswati. Data kualitatif meliputi daftar nama mahasiswa Program Studi Akuntansi Universitas Mahasaraswati. Mahasiswa Program Studi Akuntansi Universitas Mahasaraswati semester V angkatan 2017 dipilih karena mereka telah menempuh mata kuliah Etika Bisnis dan peneliti ingin mengetahui apakah tingkat kecerdasan intelektual, kecerdasan emosional, kecerdasan spiritual dan kadar love of money mahasiswa prodi akuntansi Universitas Mahasaraswati memengaruhi Persepsi Etis mereka ketika terjun ke dunia kerja dalam pengambilan keputusan. Mahasiswa yang telah menempuh mata kuliah etika bisnis menjadi suatu syarat dalam pemilihan sampel karena mahasiswa telah diajarkan untuk memahami bagaimana seharusnya seorang professional melaksanakan profesinya sesuai kode etik profesi serta sesuai dengan etika dan norma yang ada dimasyarakat. Metode pengambilan sampel yang digunakan dalam penelitian ini adalah nonprobability sampling dengan teknik sampling jenuh. Total sampel yang diperoleh adalah sebanyak 75 responden dari total populasi sebanyak 200 responden dan digunakan analisis regresi linear berganda sebagai alat pengujian.

\section{HASIL DAN PEMBAHASAN}

Pengumpulan data dilakukan melalui penyebaran kuesioner kepada Mahasiswa Program Studi Akuntansi Universitas Mahasaraswati angkatan 2017 melalui kuesioner elektronik. Jumlah responden yang diperoleh adalah 75 orang dari total populasi sebanyak 200 responden, dengan rincian responden yang berjenis kelamin perempuan sebanyak 66 orang $(88 \%)$ dan laki-laki sebanyak 9 orang $(12 \%)$.

Statistik deskriptif dalam penelitian menyajikan informasi mengenai karakteristik variabel-variabel penelitian yaitu jumlah amatan, nilai minimum, nilai maksimum, nilai mean, dan standar deviasi. Untuk mengukur nilai sentral dari distribusi data dapat dilakukan dengan pengukuran rata-rata (mean) sedangkan standar deviasi merupakan perbedaan nilai data yang diteliti dengan nilai rata-ratanya. Hasil statistik deskriptif dapat dilihat pada Tabel 1.

Tabel 1. Statistik Deskriptif

\begin{tabular}{cccccc}
\hline Variabel & N & Min. & Max. & Mean & $\begin{array}{c}\text { Std. } \\
\text { Deviasi }\end{array}$ \\
\hline Kecerdasan Intelektual (X1) & 75 & 1599,00 & 4497,00 & 3489,13 & 540,52 \\
Kecerdasan Emosional (X2) & 75 & 3745,00 & 9800,00 & 7337,64 & $1.045,56$ \\
Kecerdasan Spiritual (X3) & 75 & 2577,00 & 7584,00 & 5975,93 & 911,02 \\
Love of Money (X4) & 75 & 2204,00 & 5561,00 & 3937,55 & 779,29 \\
Persepsi Etis (Y) & 75 & 2397,00 & 7697,00 & 6070,69 & 945,80 \\
\hline
\end{tabular}

Sumber: Data Penelitian, 2020

Hasil analisis regresi linier berganda yang dirangkum dalam Tabel 2, menunjukkan nilai Adjusted $R$ Square sebesar 0,537 atau 53,7 persen, ini artinya variasi persepsi etis dipengaruhi oleh kecerdasan intelektual, kecerdasan emosional, kecerdasan spiritual, dan love of money, sisanya dijelaskan oleh variabel-variabel yang tidak dijelaskan dalam penelitian ini. Nilai signifikasi uji $\mathrm{F}$ adalah sebesar 0,000 yang lebih kecil dari 5 persen $(0,000<0,05)$. Hal ini menunjukkan bahwa model yang digunakan dalam penelitian ini adalah layak untuk digunakan sebagai alat analisis untuk menguji pengaruh variabel 
independen pada variabel dependen. Hasil pengujian ini memberikan makna bahwa seluruh variabel independen (kecerdasan intelektual, kecerdasan emosional, kecerdasan spiritual, dan love of money) mampu menjelaskan dan memprediksi persepsi etis mahasiswa akuntansi secara simultan.

Tabel 2. Hasil Analisis Regresi Linier Berganda

\begin{tabular}{ccccc}
\hline Variabel & $\begin{array}{c}\text { Unstandardized } \\
\text { Beta }\end{array}$ & Std Error & $\begin{array}{c}\text { T } \\
\text { hitung }\end{array}$ & Sig. \\
\hline Constant & 579,546 & 616,58 & 0,940 & 0,350 \\
Kecerdasan Intelektual (X1) & 0,255 & 0,208 & 1,224 & 0,225 \\
Kecerdasan Emosional (X2) & $-0,038$ & 0,121 & $-0,313$ & 0,755 \\
Kecerdasan Spiritual (X3) & 0,627 & 0,123 & 5,117 & 0,000 \\
Love of Money (X4) & 0,288 & 0,102 & 2,828 & 0,006 \\
Adjusted R & & & & 0,537 \\
F Hitung & & & & 22,442 \\
Sig. F & & & & 0,000 \\
\hline
\end{tabular}

Sumber: Data Penelitian, 2020

Kecerdasan intelektual adalah kemampuan yang dibutuhkan untuk melakukan berbagai aktivitas mental. Pratiwi (2011) merumuskan kecerdasan intelektual sebagai keseluruhan kemampuan individu untuk berpikir dan bertindak secara terarah serta kemampuan mengelola dan meguasai lingkungan secara efektif. Robbins \& Judge (2008:57) menyatakan bahwa kecerdasan intelektual adalah kemampuan yang di butuhkan untuk melakukan berbagai aktivitas mental berpikir, menalar dan memecahkan masalah. Kecerdasan intelektual menurut Yani (2011) adalah sebagai kemampuan untuk belajar dari pengalaman, berpikir menggunakan proses meta kognitif, dan kemampuan untuk beradaptasi dengan lingkungan sekitar. Kecerdasan intelektual merupakan kemampuan menganalisis, logika dan rasio seseorang. Dengan demikian, hal ini berkaitan dengan keterampilan bicara, kecerdasan akan ruang, kesadaran akan sesuatu yang tampak, dan penguasaan matematika.

Orang yang memiliki kecerdasan intelektual yang tinggi akan menggunakan logika untuk berpikir, sehingga tentunya akan lebih memahami apa yang dilakukan oleh seseorang dan apa akibat dari perbuatan itu. Hipotesis pertama pada penelitian menyatakan kecerdasan Intelektual berpengaruh positif pada persepsi etis mahasiswa akuntansi. Nilai regresi menunjukkan nilai koefisien sebesar 0,255 dengan nilai signifikasi sebesar 0,225 yang lebih besar dari a sebesar 5 persen $(0,225>0,05)$. Hasil ini mengindikasikan hasil penelitian yang tidak signifikan. Hal ini menunjukkan bahwa secara parsial kecerdasan intelektual saja tidak berpengaruh pada persepsi etis mahasiswa akuntansi. Kecerdasan intelektual dapat berpengaruh pada persepsi etis mahasiswa akuntansi ketika dibarengi dengan faktor lainnya seperti kecerdasan emosional, kecerdasan spiritual, dan love of money.

Menurut Melandy \& Aziza (2006) kecerdasan emosional memiliki peran lebih dari $80 \%$ dalam mencapai kesuksesan hidup, baik dalam kehidupan pribadi maupun kehidupan profesional. Menjadi seorang lulusan akuntansi yang berkualitas, diperlukan waktu yang panjang dan usaha yang keras serta 
dukungan dari pihak lain sehingga dapat mempengaruhi pengalaman hidup lulusan tersebut. Kecerdasan emosional merupakan kemampuan emosional yang meliputi kemampuan untuk mengendalikan diri, memiliki daya tahan ketika menghadapi suatu masalah, mampu mengendalikan emosi, memotivasi diri, mampu mengatur suasana hati, kemampuan berempati dan membina hubungan dengan orang lain. Dengan kemampuan mengenali dan mengelola emosi diri, maka individu dapat bertindak secara etis sesuai dengan norma dan nilai yang berlaku serta dengan tujuan menjaga hubungan dengan masyarakat. Nilai regresi menunjukkan nilai koefisien sebesar -0,038 dengan nilai signifikasi sebesar 0,755 yang lebih besar dari a sebesar 5 persen $(0,755>0,05)$. Hal ini mengindikasikan hasil penelitian yang tidak signifikan. Hal ini mengindikasikan bahwa secara parsial kecerdasan emosional tidak berpengaruh pada persepsi etis mahasiswa akuntansi. Kecerdasan emosional akan berpengaruh pada persepsi etis mahasiswa akuntansi ketika dibarengi dengan faktor lainnya seperti kecerdasan intelektual, kecerdasan spiritual, dan love of money.

Kecerdasan spiritual adalah kecerdasan untuk menghadapi persoalan makna atau value, yaitu kecerdasan untuk menempatkan perilaku dan hidup manusia dalam konteks makna yang lebih luas dan kaya serta kecerdasan untuk menilai bahwa tindakan atau jalan hidup seseorang lebih bermakna dibandingkan orang lain. Kecerdasan spiritual berpengaruh pada sikap etis mahasiswa akuntansi dalam mencari arti kehidupan dan bertindak berdasarkan nilai dan norma yang telah berlaku. Nilai regresi menunjukkan nilai koefisien positif sebesar 0,627 dengan nilai signifikasi sebesar 0,000 yang lebih kecil dari a sebesar 5 persen $(0,000>0,05)$. Hasil ini memiliki arti bahwa semakin tinggi tingkat kecerdasan spiritual maka semakin tinggi pula persepsi etis yang dimiliki oleh mahasiswa.

Hasil penelitian ini mendukung penelitian sebelumnya yang dilakukan oleh Maryani \& Ludigdo (2001) dengan hasil bahwa faktor religiusitas (kecerdasan spiritual) memengaruhi sikap etis akuntan. Sejalan dengan penelitian yang dilakukan oleh Ramly et al. (2008) yang menyimpulkan religiusitas (kecerdasan spiritual) berpengaruh positif terhadap perilaku etis mahasiswa universitas di Malaysia.

Pada penelitian sebelumnya mengenai pengaruh kecerdasan spiritual pada sikap etis mahasiswa akuntansi juga telah dilakukan oleh Trihandini (2005), Ika (2011), Jamaluddin (2011), Agustini \& Herawati (2013), dan Rochmah (2013). Kelima penelitian tersebut memperoleh hasil bahwa kecerdasan spiritual berpengaruh positif pada sikap etis mahasiswa akuntansi.

Love of money adalah karakter seseorang yang mendewakan uang dan love of money terkait erat dengan konsep "ketamakan" sehingga love of money dan sikap etis memiliki korelasi yang negatif dengan persepsi etis. Semakin tinggi tingkat love of money yang dimiliki seseorang, maka akan semakin rendah sikap etis yang dimilikinya, begitu pula sebaliknya. Hal ini disebabkan karena apabila seseorang memiliki kecintaan uang yang tinggi, maka ia akan berusaha untuk melakukan segala cara agar kebutuhannya terpenuhi walaupun tidak sesuai dengan etika profesinya. Nilai regresi menunjukkan nilai koefisien positif sebesar 0,288 dengan nilai signifikasi sebesar 0,006 yang lebih kecil dari a sebesar 5 persen $(0,000>0,05)$. Hasil ini memiliki arti bahwa semakin tinggi tingkat love of money seseorang maka 
semakin tinggi pula persepsi etis yang dimilikinya. Hal ini dapat dikarenakan jika seseorang mengetahui bahwa perbuatan tidak etis akan berpotensi menghilangkan aspek penting bagi kehidupannya yaitu uang (money) maka ia akan menghindari perbuatan tidak etis tersebut. Hasil penelitian ini konsisten dengan penelitian Elias \& Faraq (2010) yang menguji pengaruh Love of Money yang ternyata berpengaruh secara signifikan terhadap persepsi etis mahasiswa akuntansi.

\section{SIMPULAN}

Hasil penelitian menunjukkan bahwa kecerdasan spiritual dan love of money berpengaruh positif terhadap persepsi etis mahasiswa akuntansi. Hasil ini memiliki arti bahwa semakin tinggi tingkat kecerdasan spiritual maka semakin tinggi pula persepsi etis yang dimiliki oleh mahasiswa. Selain itu, semakin tinggi tingkat love of money seseorang maka semakin tinggi pula persepsi etis yang dimilikinya. Hal ini dapat dikarenakan jika seseorang mengetahui bahwa perbuatan tidak etis akan berpotensi menghilangkan aspek penting bagi kehidupannya yaitu uang (money) maka ia akan menghindari perbuatan tidak etis tersebut.

Kecerdasan intelektual dan kecerdasan emosional secara parsial tidak berpengaruh pada persepsi etis mahasiswa akuntansi dalam penelitian ini. Kecerdasan intelektual dapat berpengaruh pada persepsi etis mahasiswa akuntansi ketika dibarengi dengan faktor lainnya seperti kecerdasan emosional, kecerdasan spiritual, dan love of money. Demikian juga dengan kecerdasan emosional, yang akan berpengaruh pada persepsi etis mahasiswa akuntansi ketika dibarengi dengan faktor lainnya seperti kecerdasan intelektual, kecerdasan spiritual, dan love of money.

Berdasarkan kesimpulan tersebut, dapat diberikan saran untuk program studi Akuntansi Universitas Mahasaraswati untuk memberikan pemahaman yang lebih mendalam mengenai kecerdasan spiritual serta konsep love of money pada mata kuliah Etika Bisnis yang diberikan ke mahasiswa. Hal ini diharapkan akan mendorong timbulnya persepsi etis yang baik pada mahasiswa akuntansi hingga ia menjadi seorang profesional di masa yang akan datang.

Penelitian selanjutnya disarankan untuk menggunakan atau menambahkan variabel bebas lain yang diduga dapat berpengaruh terhadap persepsi etis, seperti gender, usia dan tingkat pendidikan. Populasi penelitian ini terbatas pada mahasiswa program studi akuntansi Universitas Mahasaraswati Denpasar, sehingga penelitian selanjutnya dapat memperluas populasi pada universitas yang berbeda maupun jenjang pendidikan lainnya seperti program diploma dan pascasarjana.

\section{REFERENSI}

Agustini, S., \& Herawati, N. T. (2013). Pengaruh kecerdasan intelektual, kecerdasan emosional dan kecerdasan spiritual terhadap sikap Etis mahasiswa S1 Akuntansi Universitas Pendidikan Ganesha Singaraja. EJournal Akuntansi Universitas Pendidikan Ganesha Singaraja, 1(1), 1-12. Retrieved from https://ejournal.undiksha.ac.id/index.php/S1ak/article/view/359/310 
Ajzen, I. (1988). Attitudes, Personality, and Behavior. New York: Open University Press.

Aprilianto, R., \& Achmad, T. (2017). Pengaruh Kecerdasan Emosional, Kecerdasan Intelektual, dan Love Of Money terhadap Persepsi Mahasiswa Mengenai Etika Profesi Akuntan. Diponegoro Journal of Accounting, 6(2), 1-12.

Chen, Y. J., \& Tang, T. L. P. (2006). Attitude Toward and Propensity to Engage in Unethical Behaviour: Measurement Invariance Across Major Among University Students. Journal of Business Ethics, 69(1), 77-93.

Clikemen, P. M., \& Henning, S. M. (2000). The Socialization of Undergraduate Accounting Students. Issues in Accounting Education, 15(1), 1-17. https:// doi.org/https:/ / doi.org/10.2308/iace.2000.15.1.1

Elias, R. Z., \& Faraq, M. (2010). The Relationship Between Accounting Student Love of Money and Their Ethical Perception. Managerial Auditing Journal, 25(3), 269-281. https:// doi.org/https:/ / doi.org/10.1108/02686901011026369

Fadli, M., \& Djamhuri, A. (2014). Pengaruh Kecerdasan Emosional, Kecerdasan Spiritual dan Kecerdasan Sosial Terhadap Sikap Etis Mahasiswa Akuntansi. Jurnal Ilmiah Mahasiswa FEB Universitas Brawijaya, 2(2), 1-17.

Goleman, D. (2009). Emotional Intellegence. Jakarta: PT. Gramedia Pustaka Utama.

Ika, D. (2011). Pengaruh Kecerdasan Emosional dan Spiritual Terhadap Sikap Etis Mahasiswa Akuntansi Dipandang Dari Segi Gender. Jurnal Keuangan Dan Bisnis, 3(2), 111-132.

Jamaluddin. (2011). Pengaruh Kecerdasan Intelektual, Kecerdasan Emosional, dan Kecerdasan Spiritual terhadap Etika Mahasiswa Akuntansi Fakultas Ekonomi Universitas Tadulako. Jurnal Ekonomi Dan Bisnis, 4(1), 46-56.

Lopez, Y. P., Rechner, P. L., \& Olson-Bulchanan, J. B. (2005). Shaping Ethical Perceptions: An Empirical Assessment of The Influence of Business Education, Culture, and Demographic Factors. Journal of Business Ethics, 60, 341-358.

Lucyanda, J. (2013). Faktor-Faktor Yang Mempengaruhi Perilaku Etis Mahasiswa Akuntansi Universitas Bakrie. Jurnal Ekonomi Dan Ilmu Sosial, 2(2), 1-34.

Mangiskar, L. (2019). Analisis Pengaruh Kecerdasan Emosional, Kecerdasan Spiritual , dan Love of Money Terhadap Persepsi Etis Mahasiswa Akuntansi Mengenai Etika profesi Akuntan. Maksimum Media Akuntansi Universitas Muhammadiyah Semarang, 9(2), 126-145.

Manuari, R. (2016). Pengaruh Love Of Money Pada Sikap Etis Dengan Manacika Parisudha Sebagai Pemoderasi. Universitas Udayana.

Maryani, T., \& Ludigdo, U. (2001). Survei Atas Faktor-Faktor Yang Mempengaruhi Sikap dan Perilaku Etis Akuntan. Jurnal Tema, 2, 49-62.

Mastracchio, N. J. (2005). Teaching CPAs About Serving the Public Interest. The CPA Journal, 75(1), 6,8+.

Melandy, R., \& Aziza, N. (2006). Pengaruh Kecerdasan Emosional terhadap Tingkat Pemahaman Akuntansi, Kepercayaan Diri sebagai Variabel Pemoderasi. Simposium Nasional Akuntansi 9 Padang, 1(1), 1-24.

Nkundabanyanga, S. K., Mpamizo, B., Omagor, C., \& Ntayi, J. M. (2011). The Love of Money, Pressure to Perform and Unethical Marketing Behavior in the Cosmetic Industry in Uganda. International Journal of Marketing Studies, 3(4), 
$40-49$.

Pradanti, N. R., \& Prastiwi, A. (2014). Analisis Pengaruh Love of Money terhadap Persepsi Etis Mahasiswa Akuntansi. Journal of Accounting Universitas Diponegoro, 3(3), 1-11.

Pratiwi, D. (2011). Pengaruh Kemampuan Pemakai Teknologi Informasi, Kecerdasan Intelektual, Kecerdasan Emosional, Kecerdasan Spiritual Terhadap Kinerja Karyawan. Jurnal Akuntansi Universitas Jember, 1(1), 2011.

Purwanto, N. (2003). Psikologi Pendidikan. Bandung: PT. Remaja Rosdakarya.

Ramly, Z., Chai, L. T., \& Lung, C. K. (2008). Religiosity as a Predictor of Consumer Ethical Behaviour: Some Evidence from Young Consumers from Malaysia. Journal of Business Systems, Governance and Ethics, 3(4), 43-56.

Robbins, S. P., \& Judge, T. A. (2008). Organizational Behavior (13th ed.). Bandung: CV. Alfabeta.

Rochmah, N. (2013). Pengaruh Kecerdasan Intelektual (IQ) dan Kecerdasan Spiritual (SQ) Terhadap Persepsi Mahasiswa Akuntansi Mengenai Keetisan Praktek Earnings Management. Jurnal Ilmiah Mahasiswa FEB Universitas Brawijaya, 1(2), 1-16.

Said, A. N., \& Rahmawati, D. (2018). Pengaruh Kecerdasan Intelektual, Kecerdasan Emosional Dan Kecerdasan Spiritual Terhadap Sikap Etis Mahasiswa Akuntansi (Studi Empiris Pada Mahasiswa Prodi Akuntansi Universitas Negeri Yogyakarta). Nominal, Barometer Riset Akuntansi Dan Manajemen, 7(1), 21-32. https:/ / doi.org/10.21831/nominal.v7i1.19357

Suryana, A. (2002). Indonesia Is No Stranger To Accounting Scams: Expert. Jakarta Post.

Svyantek, D. J. (2003). Emotional Intelligence and Organizational Behavior. The International Journal of Organizational Analysis, 11(3), 167-169. https://doi.org/https:/ / doi.org/10.1108/eb028969

Tang, T. . L. P. (1992). The Meaning of Money Revisited. Journal of Organizational Behavior, 12, 197-202.

Tang, T., \& Chiu, R. (2003). Income, Money Ethics, Pay Satisfaction, Commitment, and Unethical Behavior: Is The Love of Money The Root Of Evil for Hong Kong Employees? Journal of Business Ethics, 46, 13-30.

Tang, T., Tang, D., \& Luna-Arocas, R. (2005). Money Profiles: The Love of Money, Attitudes, and Needs. Personnel Review, 34(5), 603-624.

Tikollah, M. R., Triyuwono, I., \& Ludigdo, H. U. (2006). Pengaruh kecerdasan intelektual, kecerdasan emosional dan kecerdasan spiritual terhadap sikap etis mahasiswa akuntansi (Studi pada Perguruan Tinggi Negeri di Kota Makassar Provinsi Sulawesi Selatan). Simposium Nasional Akuntansi 9 Padang, $1-25$.

Trihandini, R. A. F. M. (2005). Analisis Pengaruh Kecerdasan Intelektual, Kecerdasan Emosi dan Kecerdasan Spiritual terhadap Kinerja Karyawan. Universitas Diponegoro, Semarang.

Wardana, A., \& Mimba, N. (2016). Pengaruh Kecerdasan Intelektual, Kecerdasan Emosional, Kecerdasan Spiritual, Dan Gender Pada Sikap Etis Mahasiswa Magister. E-Jurnal Ekonomi Dan Bisnis, 5(10), 3501-3530. Retrieved from http://ojs.unud.ac.id/index.php/EEB/article/view/22581

Widyaningrum, A., \& Kamayanti, A. (2013). Determinan Persepsi Etika 
mahasiswa Akuntansi Dengan Love of Money Sebagai Variabel Intervening. Jurnal Ilmiah Mahasiswa FEB Universitas Brawijaya, 2(2), 1-28.

Yani, F. (2011). Pengaruh Kecerdasan Intelektual, Kecerdasan Emosional, Kecerdasan Spiritual Terhadap Pemahaman Akuntansi. Jurnal Akuntansi Pendidikan, 1(2), 1-24.

Zohar, D., \& Marshall, I. (2007). SQ: Kecerdasan Spiritual. Bandung: Penerbit Mizan. 